\title{
Fine structure of the retinal pigment epithelium and cones of Antarctic fish Notohenia coriiceps Richardson in light and dark-conditions
}

\author{
Lucélia Donatti \& Edith Fanta
}

\begin{abstract}
Departamento de Biologia Celular, Setor de Ciências Biológicas, Universidade Federal do Paraná. Caixa Postal 19031, 81531-970 Curitiba, Paraná, Brasil. E-mail: donatti@ufpr.br
\end{abstract}

\begin{abstract}
The Antarctic fish Notothenia coriiceps Richardson, 1844 lives in an environment of daily and annual photic variation and retina cells have to adjust morphologically to environmental luminosity. After seven day dark or seven day light acclimation of two groups of fish, retinas were extracted and processed for light and transmission electron microscopy. In seven day dark adapted, retina pigment epithelium melanin granules were aggregated at the basal region of cells, and macrophages were seen adjacent to the apical microvilli, between the photoreceptors. In seven day light adapted epithelium, melanin granules were inside the apical microvilli of epithelial cells and macrophages were absent. The supranuclear region of cones adapted to seven day light had less electron dense cytoplasm, and an endoplasmic reticulum with broad tubules. The mitochondria in the internal segment of cones adapted to seven day light were larger, and less electron dense. The differences in the morphology of cones and pigment epithelial cells indicate that $N$. coriiceps has retinal structural adjustments presumably optimizing vision in different light conditions.

KEY WORDS. Photic variation; photoreceptor; retinomotor movements.
\end{abstract}

RESUMO. Ultraestrutra do epitélio pigmentar da retina e dos cones do peixe Antártico Notothenia coriiceps Richardson submetido à luz e ao escuro. O peixe Antártico Notothenia coriiceps Richardson, 1844 habita meios com variações fóticas diária e anual e as células da retina se adaptam morfologicamente a esta luminosidade ambiental. Dois grupos de peixes foram aclimatados durante sete dias à luz constante ou ao escuro constante. Após secção medular, as retinas foram extraídas e processadas para microscopia de luz e microscopia eletrônica de transmissão. No epitélio pigmentar da retina adaptado sete dias ao escuro, os pigmentos de melanina agregam-se na base coroidal das células epiteliais pigmentares e macrófagos são encontrados no interior do processos apicais entre as células fotorreceptoras. No epitélio adaptado sete dias à luz os pigmentos de melanina se dispõem ao longo das projeções apicais das células epiteliais pigmentares e os macrófagos são ausentes. A região supranuclear dos cones adaptados sete dias à luz possui um citoplasma menos elétron denso devido a presença de canais do retículo endoplasmático que se dilatam aumentando o seu lúmen. As mitocôndrias existentes no segmento interno dos cones adaptados à luz são maiores, e menos elétron densas. As diferenças na morfologia dos cones e nas células epiteliais pigmentares indicam que $N$. coriiceps possui mecanismos celulares de ajustes na retina provavelmente otimizando a capacidade visual em diferentes situações de luz.

PALAVRAS-CHAVE. Fotorreceptor; movimento retinomotor; variação fótica.

The eyes of teleost fish adapt to different light levels through changes in retinal structure. Some of these retinal changes in response to light cycles include: movements of the myoid (AREY 1975), migration of melanin granules (Es-souNNI \& AlI 1986, BuRNSIDE 2001) and fluctuations in the pre-synaptic membrane and the terminal buttons (BRAEKEVELT et al. 1998b, Burnside 2001), among others. Es-sounni \& Ali (1986) and BraekeVelt et al. (1998a) reported several changes when comparing the retina of teleost fish adapted to light and to darkness. These included a change in the shape of lipids droplets, detachment of outer segments of photoreceptors, formation of multilobular bodies, alterations in the number of macrophages and melanolysosomes, and other organelles.

Retinomotor or photomechanical movements are characterized by the migration of cones, rods and pigment epithelium in response to changes in environmental light conditions (Ali 1971, Eastman 1988, MacDonald \& Montgomery 1991, BURNSIDE 2001).

Cells of the retinal pigment have been shown to have a mechanism to transport melanin granules not only in response 
to changes in light levels (ALI 1975) but also through regulation by endogenous circadian rhythms (ALI 1975). However if the pigment epithelial cells are isolated from the retina, they do not respond to changes in light (BRUENNER \& BURNSIDE 1986). In light adapted retinas, the prostaglandin El can induce retinomotor movement in cones and pigment epithelial cells (Cavallaro \& Burnside 1988).

The cytoskeleton and the endoplasmic reticulum are two cell elements involved in photomechanical adaptation to darkness and light (FERRERo et al. 1979). These photomechanical responses involve elongation of the myoid in photoreceptors, and a redistribution of microtubules that slide al ong the length of myoid. This sliding is generated by the interaction of microtubules distributed as stripes in specific myoid regions (W ARREN \& BuRnSIDE 1978). The distribution and appearance of the endoplasmic reticulum in the internal segment of the photoreceptors changes with adaptation to light. As the inferior ellipsoid of cones and rod elongates the density of the endoplasmic reticulum is reduced (FERRERo et al. 1979).

Fish habitats and retinal responses are related. Depending on species and life stage, fish live in a variety of habitats with different light regimes, from surface water to great depths, and they may make extensive diurnal vertical migrations. The interspecific differences in retinal responses under different light conditions may be a consequence of ecological adaptations. Species may be adapted to a certain light regime and adaptation to light is often faster than adaptation to dark (ALI \& $\mathrm{H}_{\text {ANYU }}$ 1963, AlI \& ANCTIL 1968, Alı 1971). Retinomotor responses may be related to behavior in schooling fish (KeENLEYSIDE 1955, LOUKASHKIN \& GRANT 1959), or to feeding and migration (ALI 1971, FANTA et al. 1994, DonATTI \& FANTA 2002), among other factors.

Notothenia coriiceps Richardson, 1844 (Nototheniidae) lives in relatively shallow coastal Antarctic waters, where the photoperiod and light quality in terms of wavelength can vary significant on a daily and/or seasonal. Acknowledging the occurrence of this variation our objectives included a qualitative description of ultrastructural morphological changes and functional strategies of the retina that enable the visual system of Notothenia coriiceps to function in light and darkness.

\section{MATERIAL AND METHODS}

N otothenia coriiceps was collected by trammel net in Admiralty Bay (6209'S, 5826'W), King George Island, South Shetlands, Antarctica, at about $20 \mathrm{~m}$ depth, during the summer (December and January) of 1998/1999. Individuals of a total length of $36.5 \pm 2 \mathrm{~cm}$ (mean \pm S.D.) $(\mathrm{n}=28)$ were maintained in light proof tanks, under controlled conditions at the Brazilian Antarctic Station Comandante Ferraz.

The well-aerated water was kept at a temperature of $0 \pm$ 0.5 으 (mean \pm S.D.), $\mathrm{pH} 7.0 \pm 0.5$ (mean \pm S.D.), and salinity $34.5 \pm 1.0$ ppt (mean \pm S.D.). Groups of $14 \mathrm{~N}$. corriceps were maintained for seven days in continuous light, or continuous darkness. Darkness tanks were covered with a black light proof sheet. For continuous light conditions, a daylight fluorescent lamp was on above the tank and remained on all during the experiment.

Fish were euthanized by medullar section and after decerebration the retinas of dark adapted fish were extracted and fixed under a low level red light. Light adapted fish retinas were extracted under daylight fluorescent lamp.

For optical microscopy, retinas were fixed in Bouin's fluid for eight hours (Culling et al. 1985) and processed routinely for traditional histology according to CLARK (1981). Samples were embedded in Paraplast Plus ${ }^{\circledR}$ (Sigma), sectioned at 2-4 $\mu \mathrm{m}$, stained with Haematoxylin-Eosin (H.E.) and photomicrographs were taken with a photomicroscope (model PM 10AD, Olympus, Japan).

For transmission electron microscopy, the retinas were cut into small pieces and fixed in modified Karnovsky at 4으 (Culling et al. 1985). During post fixation a $2 \%$ solution of osmium tetroxide buffered in $0.2 \mathrm{M}$ cacodylate $(\mathrm{pH}$. 7.2) was used, and samples were contrasted with $2 \%$ uranyl acetate. The samples were dehydrated in an ethanol series, embedded in Epon-812 in a balanced mixture (Lurt 1961). The contrast of sections was enhanced with $2 \%$ uranyl acetate (W ATSON 1958), and lead nitrate (REYNOLDS 1963). They were examined under a electron microscope (JEM 1200 EXII, JEOL, Japan).

\section{RESULTS}

Notothenia coriiceps has a retina with ten cells layers. However, fish adapted to 7-day light or seven day dark conditions differed in some retinal properties. The position of the melanin pigment in the pigment epithelium differed in both light regimes (Figs 1 and 2). After seven day in the dark the melanin granules were aggregated in the coroidal base of the pigmented epithelial cells, exposing the tips of the external segments of the photoreceptors (Fig. 3). After seven days under light the melanin pigment was located inside the apical projections of the pigment epithelium cells, protecting the external segments of the photoreceptors (Fig. 4).

When adapted to dark conditions, the pigment epithelium contained more membranes detached from the external segments of the photoreceptors, dispersed in its cytoplasm, more phagosomes, and more myeloid bodies associated with lipid droplets (Figs 5, 6 and 8). Macrophages were found close to the Bruch's membrane and alongside the apical processes, between the photoreceptors (Fig. 7). There were no macrophages in the pigment epithelium of animals adapted to light.

In cones, the region of the myoid and ellipsoid that form the internal segment underwent changes during adaptation. Light adapted cones were shorter than dark adapted. After seven days in light conditions ellipsoids of cones were closer to the external limiting membrane than after seven days in the dark, and the ellipsoids and myoids were not distinguishable, the neck having disappeared (Fig. 9). Dark adapted cones became elongated and had clearly defined regions, the ellipsoid, myoid, su-

Revista Brasileira de Zoologia 24 (1): 33-40, março 2007 


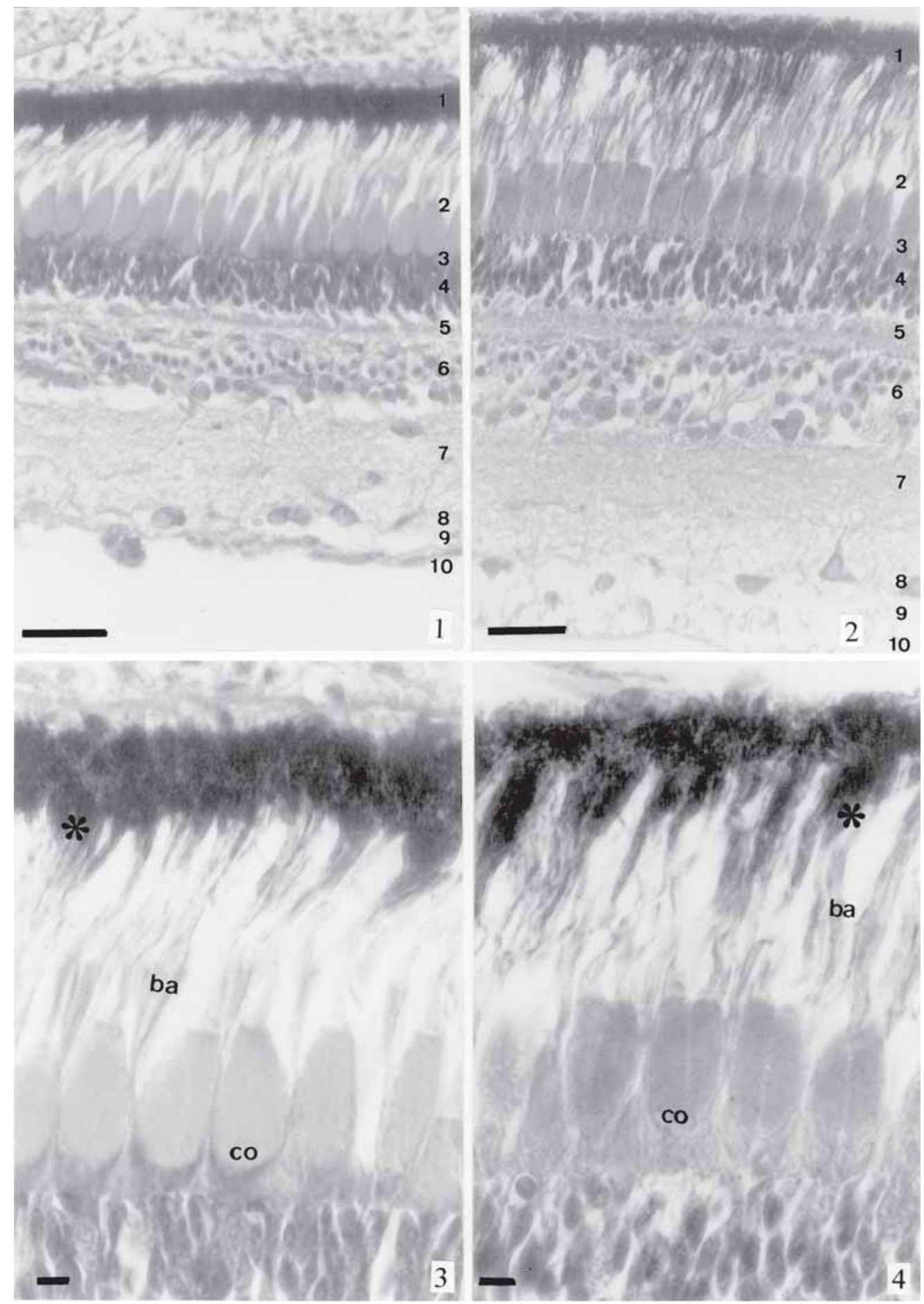

Figures 1-4. Organization of the retina of N otothenia coriiceps: (1) seven day dark-adapted retina; and (2) seven day light-adapted retina. Observe the 1) pigment epithelium, 2) cones and rods, 3) external limiting membrane, 4) external nuclear layer, 5) external plexiform layer, 6) internal nuclear layer, 7) internal plexiform layer, 8) ganglionar cells, 9) optical nerve fibers, 10) internal limiting membrane (H.E.) (scale: $100.000 \mathrm{~nm}$ ). (3) Detail of photoreceptors adapted to seven day darkness; and (4) adapted to seven day light. Observe the melanin granules (asterisk), cones (co), and rods (ba) (H.E.) (scale: $10.000 \mathrm{~nm}$ ). 


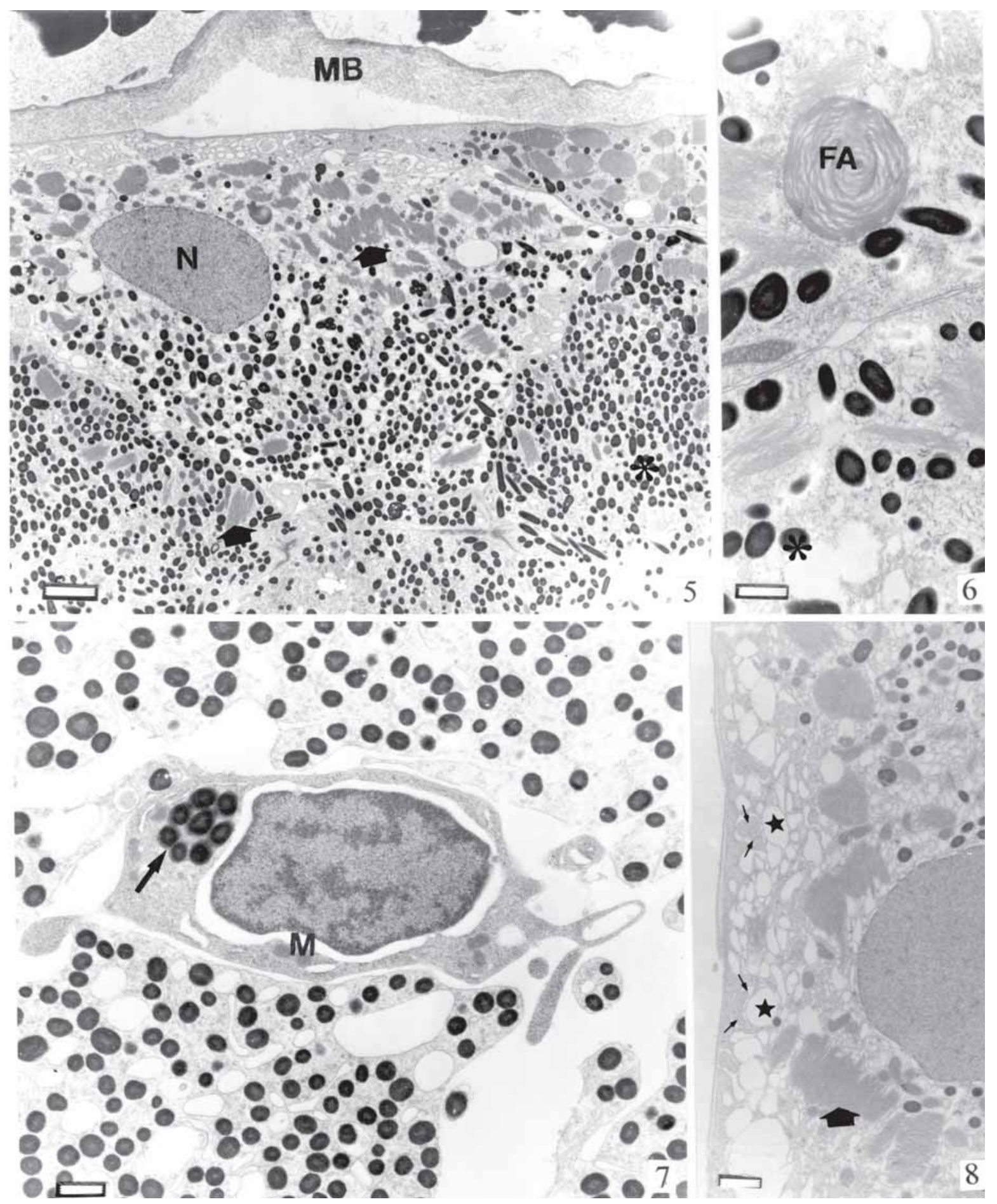

Figures 5-8. Pigment epithelium of seven day dark-adapted N otothenia coriiceps: (5) pigment epithelium with Bruch's membrane (MB), melanin pigment (asterisk), nucleus $(\mathrm{N})$, detached membranes of photoreceptor external segments (arrow) (scale: $2.000 \mathrm{~nm}$ ); (6) phagosome (FA) in the cytoplasm of epithelium cells and melanin pigments (asterisk) (scale: $500 \mathrm{~nm}$ ); (7) Macrophages (M) with phagosomes (arrow) in the pigment epithelium (scale: $500 \mathrm{~nm}$ ); (8) myeloid corpuscles (thin arrow) associated with lipid droplets (star). Notice that detached membranes of the external segment of photoreceptors (thick arrow) (scale: $1.000 \mathrm{~nm}$ ).

Revista Brasileira de Zoologia 24 (1): 33-40, março 2007 

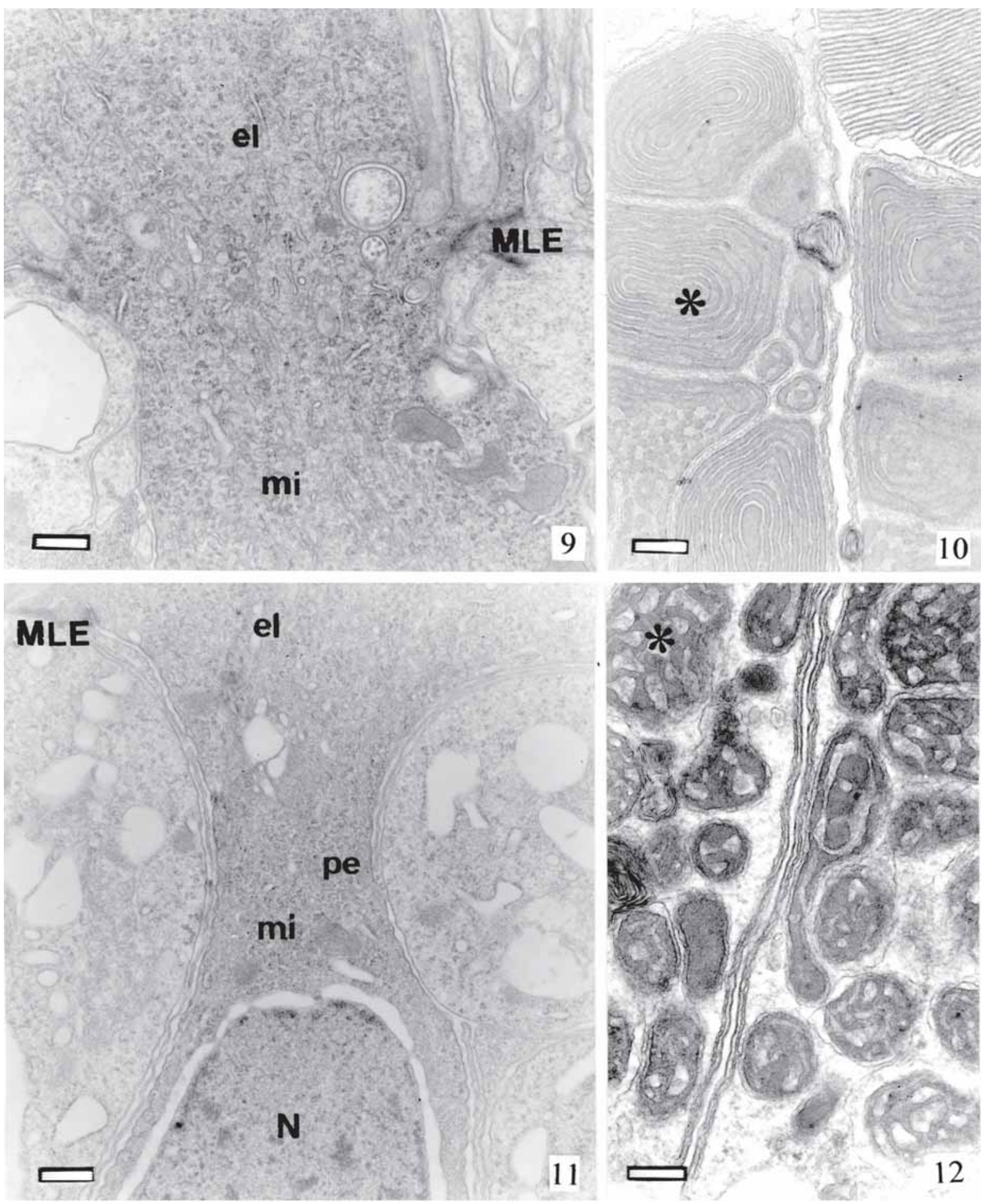

Figures 9-12. Internal segment of cones in Notothenia coriiceps: (9) myoid (mi) and ellipsoid (el) in a cone adapted to seven day light. Notice the less electrondense cytoplasm and the external limiting membrane (MLE) (scale: $500 \mathrm{~nm}$ ); (10) mitochondria (asterisk) in a cone adapted to seven day light (scale: $200 \mathrm{~nm}$ ); (11) myoid (mi), ellipsoid (el) and neck (pe) of a cone adapted to the seven day dark, with electron dense cytoplasm, nucleus (N), and external limiting membrane (MLE) (scale: $500 \mathrm{~nm}$ ); (12) Mitochondria (asterisk) in a cone adapted to seven day dark (scale: $200 \mathrm{~nm}$ ). 

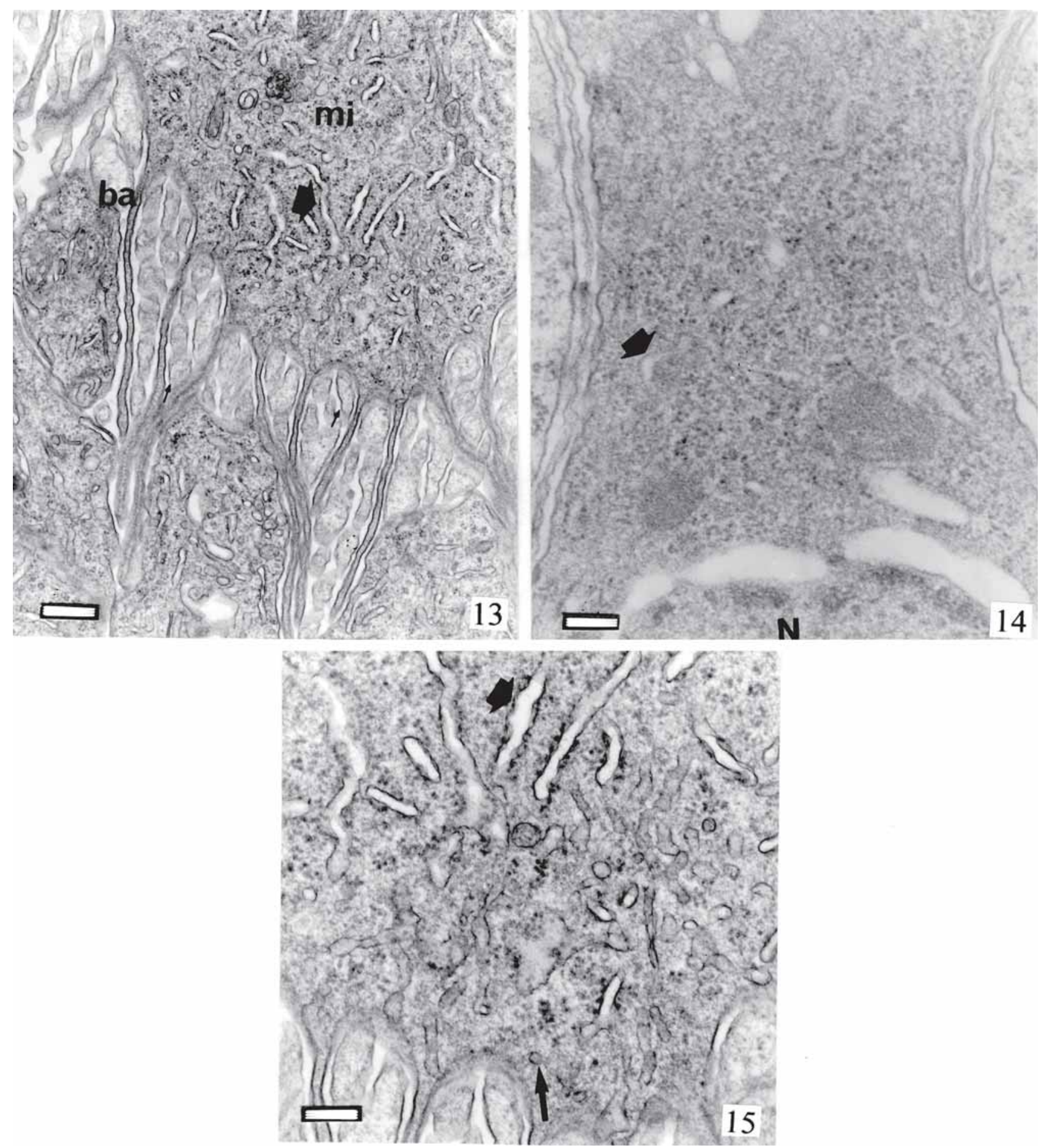

Figures 13-15. Myoid region of a cone of Notothenia coriiceps: (13) myoid region of a cone adapted to seven day light. Notice the endoplasmic reticulum (thich arrow), the fins (ba), and the Müller cell extensions (small arrow) (scale: $500 \mathrm{~nm}$ ); (14) myoid region of a cone adapted to seven day dark. Notice the endoplasmic reticulum (thick arrow) and nucleus (N) (scale:200); (15) microtubules (thin arrow) and endoplasmic reticulum (thick arrow) at the myoid of a cone adapted to seven day light (scale: $200 \mathrm{~nm}$ ).

Revista Brasileira de Zoologia 24 (1): 33-40, março 2007 
pranuclear region and neck (Fig. 11). The mitochondria in the ellipsoids were more electron-dense and smaller in dark conditions when compared to light conditions (Figs 10 and 12).

The supranuclear region was less electron-dense in cones adapted to daylight than in those adapted to darkness, because the tubules in the endoplasmic reticulum expand, enlarging the lumen of the endoplasmic reticulum (Figs 13 and 15). In seven day dark adapted cones, the cytoplasm is more electron dense and the endoplasmic reticulum has no enlarged tubules (Fig. 14).

\section{DISCUSSION}

The retina of Notothenia coriiceps is composed of ten histological layers, being similar to that of several other notohenioids and typical teleosts (EASTMAN 1988, GrötZner \& Fanta 1998, Donatti \& Fanta 2001, Fanta et al. 2001). They exhibit four types of cones, rods, pigmented epithelium and neuronal layers (GrötZer \& FANTA 1998, DonATTI \& FANTA 2001).

Some authors have described the retinal organization and visual function of Notothenioid fish (FANTA et al. 1994, 1999, 2001, Grötzer \& Fanta 1998, MacDonald \& Montgomery 1998, DoNATTI \& FANTA 2001, 2002). However, there are several changes in the retinal ultrastructural characteristics that occur as a consequence of adaptation to continuous light or dark conditions that were not yet qualitatively described. This study detected structural differences in retinas of light and dark adapted Notothenia coriiceps related to retinomotor movements, tubules of endoplasmatic reticulum, and to the density of cytoplasm and mitochondria.

The extent of retinomotor movements in retinal photoreceptors, and pigment epithelium, are indicators of the activity of the retina. Usually, isovolumetric changes, similar to those of a muscle contraction, are attributed to a system of microtubules in the photoreceptors (BURNSIDE 1978, W ARREN \& BURNSIDE 1978). Retinomotor movements reposition photoreceptor outer segments and screening pigment in the retinal pigment epithelium so that photoreceptors are optimally exposed to incoming light in the dark in the case of rods and under light conditions in the case of cones (ALI 1971, 1975). This capacity might be important for $\mathrm{N}$. coriiceps to enable the fish to find their prey under light and dark conditions, or even when weather changes, resulting in sudden changes in light conditions. (DONATTI \& FANTA 2002)

A higher number of detached membranes of the external segment of photoreceptors, and the presence of macrophages was observed in the pigment epithelium of $\mathrm{N}$. coriiceps adapted to darkness. This loss of the outer segments of photoreceptors followed by phagocytosis by the pigment epithelium cells is normal in some retinas (BALKeMA \& Bunt-MILAM 1982, Braekevelt et al. 1998a, Donatti \& Fanta 1999), due to rhythmic turnover of its cellular organelles (O'DAY \& Young 1978, BrAeKEVELt 1980), and is intensified in consequence of higher photoreceptors activity. The balance between membrane syn- thesis and degradation maintains the external segment, mainly of rods, in a relatively constant length. The removal of these external segments can be done macrophages (BRAEKEVELT 1980), which would explain their presence in the pigment epithelium in this study. In contrast, evidence of disk shedding by cones is very rare, and has not been show to be a regularly recurring process. (O'DAY \& Young 1978). They do not exist given in the literature that explains the occurrence of a higher number of detached membranes of the external segment of photoreceptors in the animals adapted to darkness

Lipid droplets, associated with the myeloid body, were found in greater quantity in the dark-adapted retina. Their number can increase due to the degradation of phagosomes, and this may explain the lipid droplets in dark-adapted N. corriceps.

In N. coriiceps adapted to darkness the presence of electron dense cytoplasm, and an endoplasmic reticulum with tubules that have a small diameter, indicates a reduction in

synthetic activity and in the release of metabolites to the external segment of photoreceptors.

The qualitative analysis of the retina of $\mathrm{N}$. coriiceps demonstrates that this species presents the typical cellular and subcellular mechanisms for retinal structural adjustments that can optimize the visual function of the retina.

\section{ACKNOWLEDGEMENTS}

The authors thank: the CNPq for financial support (Projects number 490.103/99-5 and 480.265/00-3), and for a Productivity in Research Stipend to E. Fanta (300.831/93-5); the CAPES for a PICDT-Doctorate Stipend to L. Donatti; the SECIRM (Brazilian Navy) and the staff of the Brazilian Antarctic Station Comandante Ferraz for all logistical support and I. Everson (BAS, UK) for valuable suggestions to the manuscript.

\section{REFERENCES}

ALı, M.A. 1971. Les résponses retinomotrices: caractères et mecanismes. Vision Research 11: 1225-1228.

Alı, M.A. 1975. Retinomotor responses, p. 315-355. In: M.A. A tı (Ed.). Vision in Fishes. New York, Plenum Press, 836p.

Alı, M.A. \& I. HanYu. 1963. A comparative study of retinal structure in some fishes from moderately deep waters of the Western North Atlantic. Canadian Journal of Zoology 41: 225-241.

Alı, M.A. \& M. AnCtil. 1968. Correlation entre la structure rétinienne et I'habitat chez Stizozteidon vitreum vitreum et $\mathrm{S}$. Canadense. Journal of the Fisheres Research Board of Canada 25: 2001-2003.

AREY, L.B. 1975. The occurrence and the significance of photomechanical changes in the vertebrate retina - an historical survey. Journal Comparative Neurology 25: 535-554.

Balkema, G.W.JR \& A.H. Bunt-Milam. 1982. Cone outer segment shedding in the goldfish retina characterized with ${ }^{3} \mathrm{H}$-fucose technique. Investigative Ophthalmology and Visual Science 23: 319-331.

Revista Brasileira de Zoologia 24 (1): 33-40, março 2007 
Braekevelt, C.R. 1980. Wandering phagocytes at the retinal epithelium-photoreceptor interface in the teleost retina. Vision Research 20: 495-499.

Braekevelt, C.R.; S.A. Smith \& B.B. Simith. 1998a. Fine structure of the retinal pigment epithelium of Oreochromis niloticus $L$. (Cichlidae; Teleostei) in light- and dark-adaptation. The Anatomical Record, Oakland, 252: 444-452.

Braekevelt, C.R.; S.A. Smith \& B.B. Smith. 1998b Photoreceptor finestructure in Oreochromis niloticus L. (Cichlidae; Tel eostei) in light- and dark-adaptation. The Anatomical Record 252: 453-461.

Bruenner, U. \& B. Burnside. 1986. Pigment granule migration in isolated cells of the teleost retinal pigment epithelium. Investigative Ophthalmology \& Visual Science 27: 16-34.

Burnside, B. 1978. Thin (actin) and thick (myosin like) filaments in the cone contraction of teleost retina. Journal of Cell Biology 78: 227-246.

BURNSIDE, B. 2001. Liht and circadian regulation of retinomotor movement. Progress in Brain Research 131: 477-485.

Cavallaro, B. \& B. Burnside. 1988. Prostaglandins E1, E2 and D2 induce dark-adaptive retinomotor movements in teleost retinal cones and RPE. Investigative Ophthalmology \& Visual Science 29: 882-891.

CLARK, G. 1981. Staining procedures. Baltimore, Willians \& Wilkins, 512p.

Culling, C.F.A.; R.T. Allison \& W.T. Barr. 1985. Cellular Pathology Technique. London, Butterworth, $4^{\text {th }}$ ed., 642p.

DonATTI, L. \& E. FANTA. 1999. Morphology of the retina in the freswater fish Metynnis rooseveti Eigenmann, 1915 (Characidae, Serrasalminae) and the effects of monochromatic red light. Revista Brasileira de Zoologia 16 (1): 151-173.

DonATTI, L. \& E. FANTA. 2001. Ultrastructure of photosensory cells and pigment epithelium in the retina of the Antarctic fish Notothenia neglecta Nybelin (Nototheniidae). Antarctic Record 45 (3): 297-310.

DONATTI, L. \& E. FANTA. 2002. Influence of photo period on visual prey detection in the antarctic fish Notothenia neglecta Nybelin. Antarctic Science 14 (2): 146-150.

EAstman, J.T. 1988. Ocular morphology in Antarctic notothenioid fishes. Journal Morphology 196: 283-306.

Es-sounNı, A. \& M.A. Alı. 1986. Ultrastructure of the retinal pigment epithelium of light-and dark-adapted Young pigmented, and mature silver eels, Anguilla anguilla (pisces, Teleostei). Zoomorphology 106: 179-184.

FantA, E.; A.A. Meyer; S.R. Grötzner \& M.F. Luvizotto. 1994. Comparative study of the feeding strategy and activity patterns of two Antarctic fish Trematomus newnesi Boulenger, 1902 and Gobionotothen gibberifrons (Lönnberg, 1905) (Pisces, Nototheniidae) under different light conditions. Antarctic
Record 38: 13-29.

FantA, E.; F.S. Rios; A.A. Meyer \& S.R. Grötzner. 2001. Chemical and visual systems in feeding behaviour of the Antarctic fish Ophthalmolycus amberensis (Teleostei, Zoarcidae). Antarctic Record 38: 13-29.

Fanta, E.; L. Donatti \& S. Fraiberguer. 1999. Visual sufficiency in food and initiation of feeding behaviour in the antarctic fish trematomus newnesi Boulenger, 1902. Antarctic Record 43 (2): 221-236.

Ferrero, E.; M. Anctil \& M.A. Alı. 1979. Ultrastructural correlates of retinomotor responses in inner segments of vertebrate photoreceptors. Révue Canadiennede Biologie 38: 249-264.

GrötZer, S.R. \& E. FAntA. 1998. Comparative morphology of the retina of the Antarctic fish Gobionotothen gibberifrons (Lönnberg, 1905), Trematomus newnesi Boulenger, 1902, Lepidonotothen nudifrons (Lönnberg, 1905) and Notothenia neglecta Nybelin, 1951. Pesquisa Antártica Brasileira 3: 3147.

KeEnleyside, M.H.A. 1955. Some aspects of the schooling behaviour of fish. Behaviour 8: 183-248.

LoukASHKIn, A.S. \& N. GRANT. 1959. Behaviour and reactions of the Pacif sardine, Sardinops caerula (girad), under the influence of white and colored lights and darkness. Proceedings of the California Academic of Sciences 29 (15): 509-548.

LUFT, J.H. 1961. Improvements in epoxy resin embedding methods. The Journal of Biophysical and Biochemical Cytology 9: 409-414.

MacDonald, J.A. \& J.C. Montgomery. 1991. The sensory biology of notothenioid fish, p. 145-162. In: G. DI PRISCO; B. M ARESCA $\&$ B. TотA (Eds). Biology of Antarctic Fish. Berlim, Springer Verlag, 292p.

MacDonald, J.A. \& J.C. Montgomery. 1998. Evolution of sensoty systems: a comparison of Antarctic and deep-sea ichthyofauna, p. 329-338. In: G. DI Prisco; E. Pisano \& A. Clarke (Eds). Fishes of Antarctica: a biological overview. Milan, Springer Verlag, 363p.

O'DAY, W.T. \& R.W. Young. 1978. Rhythmic daily shedding of outer-segment membranes by visual cells in the goldfish. Journal of Cell Biology 76: 593-604.

ReYnolds, E.S. 1963. The use of lead citrate at high $\mathrm{pH}$ as an electron-opaque stain in electron microscopy. Journal of Cell Biology 17: 208-212.

W ARREN, R.R. \& B. BURNSIDE. 1978. microtubules in cone myoid elongation in the teleost retina. Journal of Cell Biology 78: 247-259.

Watson, M.L. 1958. Staining of tissue sections for electron microscopy with heavy metals. The Journal of Biophysical and Biochemical Cytology 4 (4): 475-478.

Received in 21.III.2006; accepted in 28.II.2007.

Revista Brasileira de Zoologia 24 (1): 33-40, março 2007 